\title{
A STUDY OF THE ECOLOGICAL EFFECTS OF WATER SUPPLEMENT CONDITIONS IN EBINUR LAKE
}

\author{
YU, X. ${ }^{1}-$ ZHUGE, Y. ${ }^{*}-$ LI, G. ${ }^{1}-$ DU, Q. ${ }^{1}-$ ZHANG, D. ${ }^{2}-$ TAN, H. ${ }^{1}-$ ZHANG, S. ${ }^{1}$ \\ ${ }^{1}$ China Institute of Water Resources and Hydropower Research \\ A-1 Fuxing Road, Haidian District, 100038 Beijing, PR China \\ ${ }^{2}$ Xinjiang Boyan Environmental Water Conservancy and Hydropower Technology Co., Ltd. \\ Urumqi, Xinjiang, PR China \\ *Corresponding author \\ e-mail: zhugeys@iwhr.com \\ (Received 30 $0^{\text {th }}$ Jul 2018; accepted $5^{\text {th }}$ Oct 2018)
}

\begin{abstract}
The lack of environmental water storage of Ebinur Lake has led to a serious degradation of the ecological system. The efficient water supplement and its ecological effect of Ebinur Lake were studied in this paper. Based on the lake terrain and water-salt balance analysis, the area restoration target and water supplement of Ebinur Lake were determined as $755 \mathrm{~km}^{2}$ and 366 million $\mathrm{m}^{3}$, respectively. An efficient water supplement process was perennial water flowing from October to the next March every year. In this study, through an inversion and comparative analysis of lake area and salinity from 1956 to 2011 , it was found that the multi-year average lake area was $387 \mathrm{~km}^{2}$ and the salinity was $173 \mathrm{~g} / \mathrm{L}$ under the condition of actual river inflow, and those were $661 \mathrm{~km}^{2}$ and $102 \mathrm{~g} / \mathrm{L}$ under the condition of water supplements respectively. The area with year-round salinity suitable for artemia growth accounted for $34 \%$ and $87 \%$ namely under the two conditions. The research results indicated that the water supplements could effectively restore the area of Ebinur Lake and be conducive to the artemia growth in the lake area. The ecosystem of Ebinur Lake was found to be developing in a favorable direction.
\end{abstract}

Keywords: efficient water supplement, hydrodynamic and salinity mathematical models, lake area, salinity, ecological effects

\section{Introduction}

Located in the hinterland of the Eurasian continent, Ebinur Lake lies on the southwest margin of the Junggar Basin. The lake shares the characteristics of a typically closed saline lake in an arid area, and is the main hub of the "East Africa-West Asia Migratory Route" for the world's migratory bird populations (Ma et al., 2010; Bayahen, 2010). In addition, the area is a critial place of the New Eurasia Continental Bridge as it is one of six strategic maior areas of the "One Belt, One Road" project (Abuduwaili, 2012).

Since the 1950s, Ebinur Lake has been continuously shrinking. The water area has shrunk from over $1,000 \mathrm{~km}^{2}$ in the early days of New China, to less than $500 \mathrm{~km}^{2}$ in 2011. Moreover, the water storage capacity of Ebinur Lake has decreased from 3 billion $\mathrm{m}^{3}$ to 600 million $\mathrm{m}^{3}$ (Zhang et al., 2015; Wang et al., 2017; Zhu et al., 2018). The water reduction of Ebinur Lake has led to the serious recession of lakeshore vegetation, with $60 \%$ of the desert forest around the lake vanishing. The desertification area is known to be expanding at a speed of $39.8 \mathrm{~km}^{2}$ per year on average. From the Alataw Pass to Jing River Station along the New Eurasia Continental Bridge, $70 \mathrm{~km}$ of railway line has suffered from the harmful effects of the soluble-salt wind-sand flows and migratory dunes of Ebinur Lake (Abuduwaili, 2012). Besides, with the gradual shrinking of the lake water area, the salinity of Ebinur Lake has increased from less than $90 \mathrm{~g} / \mathrm{L}$ in the 1960 s, to approximately $200 \mathrm{~g} / \mathrm{L}$ in 2008 , which is more than 20 times the 
salinity levels of Qinghai Lake (Yan et al., 2018; Chen, 2007). The high salinity level of the lake water has led to a singular ecosystem structure of Ebinur Lake area, and no fish distributions are present. It has been observed that only artemia are able to flourish in such a high-salt environment. Artemia is a major food source for migratory birds, for which the highest suitable salinity is between 50 and $150 \mathrm{~g} / \mathrm{L}$ (Mulian et al., 1992). In 2011, the trend of increasing salinity levels of Ebinur Lake poses a serious threat to the survival of the artemia there.

Since the environmental water storage deficiency in Ebinur Lake would potentially cause the above ecological environment problems, and considering that Ebinur Lake is located in the hinterland with objective contradictions between the supply and demands of water, water supplement from other basins is an effective way to solve the problem of water shortage in Ebinur Lake (Su Qin, 2015). In this study, the efficient water supplement of Ebinur Lake and its ecological effects were examined under the conditions of the limited water resources. An efficient water supplement process and method for Ebinur Lake were proposed based on the research results. Hydrodynamic and salinity mathematical models of Ebinur Lake were utilized, and the lake area and salinity were inversed for a comparative analysis of the potential impacts of water supplements. The results of the current research provided a scientific basis for the implementation of an ecological water supplement program concerning Ebinur Lake.

\section{Materials and methods}

\section{Study area}

Ebinur Lake, which is also known as Kul Lake, is located in the Alataw Pass Wind Channel Area on the border between China and Kazakhstan. This region is one of the four largest wind areas and is considered to be a "world class" wind port of the southwestern Junggar Basin, Xinjiang, Northwest China. Ebinur Lake is also the largest salt lake in Xinjiang (Fig. 1). The Ebinur Lake Basin is characterized by a descending topography from west to east with a depression at the center, where the lake area has its lowest depression as the tail-end lake of the basin. Ebinur Lake is a typical closed salt lake in an inland arid area (Zhang et al., 2015; Sumin and Hongshen, 1998). This basin is located far from the Pacific Ocean, and a typical temperate continental climate prevails in this region. The strong winds of the Alataw Pass are the dominant factors affecting the local climate. In most areas of this basin, the climate is characterized by cold winter, hot summer, and dry and windy spring. The multi-year annual average rainfall is $90.9 \mathrm{~mm}$, and multi-year average water surface evaporation is $1,315 \mathrm{~mm}$. The multi-year average temperature is $7.8^{\circ} \mathrm{C}$, and annual average wind speed is $6.0 \mathrm{~m} / \mathrm{s}$. Annual gale days is 164 (wind speed greater than $8 \mathrm{~m} / \mathrm{s}$ ) with the maximum wind speed of $55.0 \mathrm{~m} / \mathrm{s}$ (Jin, 1995; Liu et al., 2014).

There are 47 rivers flowing into Ebinur Lake. However, most of the rivers in the area have dried up, except the Bortala and Jing Rivers with no outlet for the lake (Zhang et al., 2015). The lake displays the "NW-ES" trend of a quasi-rectangular elliptic lake, Its lakebed is flat and saucer shaped, and the water levels are that of a shallow lake. In 2011, the water depth is $1.4 \mathrm{~m}$, with the lowest terrain located in the southeastern section. In the northern section of the lake, a sand ridge is located across the lake in a direction which is perpendicular to the lake trend. As a result, Ebinur Lake is divided into two lakes when water levels become low. Therefore, a northwestern small lake and southeastern big lake coexist, while the big lake owns most of the river water supply. 


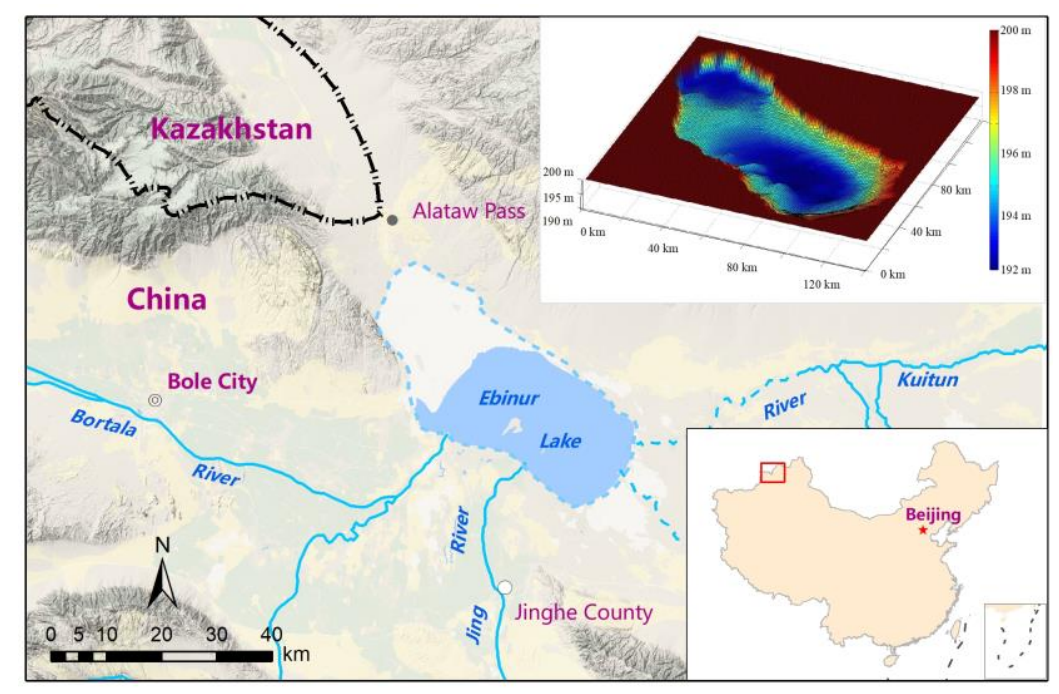

Figure 1. Position and topographical map of Ebinur Lake

Due to the negative conditions of low rainfall and high evaporation levels in the basin, the area of Ebinur Lake is prone to recede under the high wind effects of the Alataw Pass. In addition, due to the large-scale development and water usage in the basin during recent decades, the in-flowing water has been greatly reduced. Overall, the lake area has shrunk from $1,200 \mathrm{~km}^{2}$ in the $1950 \mathrm{~s}$, to approximately $500 \mathrm{~km}^{2}$ in 2011 (Zhang et al., 2015; Jin, 1995). The small lake located in the main wind channel of the Alataw Pass has completely receded. The surface salt dust particles of the exposed lakebed are blown to the oasis on the northern slope of Tianshan Mountain in a downwind direction under the action of the high winds, or even into parts of northern China $5,000 \mathrm{~km}$ away. This transportation of dust particles poses a serious threat to the security of the regional ecological. Ebinur Lake has become one of the main origins of dust storms in western China (Liu et al., 2014; Abuduwaili et al., 2008). Furthermore, due to the shrinking of Ebinur Lake area, the lake's salinity levels have gradually increased. In the 1950s, the lake salinity was $87.2 \mathrm{mg} / \mathrm{L}$. However, it had increased to between 163 and $191 \mathrm{~g} / \mathrm{L}$ in 2006 to 2011. In 2008, the salinity levels in parts of the lake were found to be as high as $202 \mathrm{~g} / \mathrm{L}$ (Fig. 2) (Zhu et al., 2018; Jin, 1995).

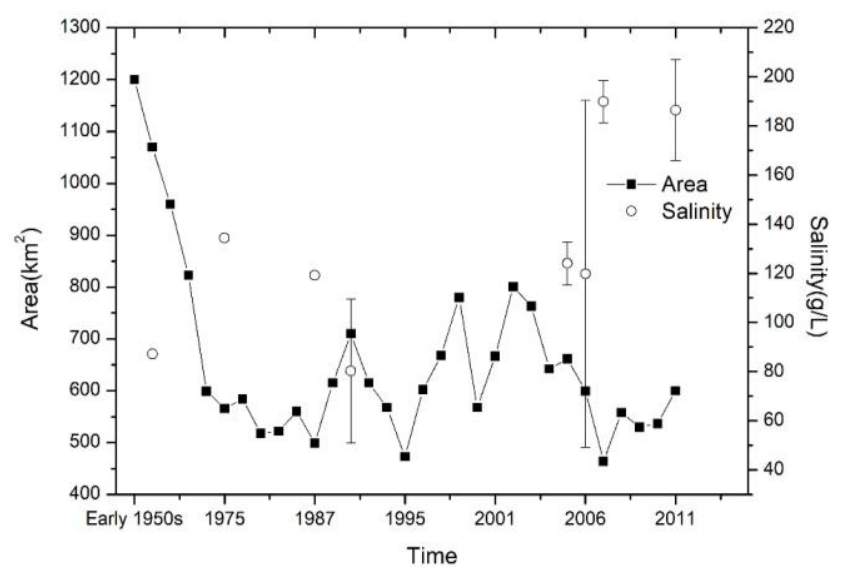

Figure 2. Interannual trend variations in the area size and salinity levels of Ebinur Lake 


\section{Research methods}

Analysis of the water-salt balance in the study area

In order to quantitatively analyze the ecological effect of water supplement in Ebinur Lake, water-salt balance calculation is conducted in this investigation to determine the water quantity and process of efficient water supplement. It was observed that the only water output was the evaporation of Ebinur Lake's surface. The input included rainfall, runoff and groundwater discharges. The increases in the total salt content were mainly caused by the surface and underground water carrying salt. The losses of salt content were mainly due to wind erosion. The results of this water and salt balance analysis are shown in Equations (1) and (2), respectively (Sheng et al., 2010; Riveros-Iregui et al., 2017).

$$
\begin{gathered}
\Delta \mathrm{V}=\mathrm{V}_{\text {rainfall }}+\mathrm{V}_{\text {runoff }}+\mathrm{V}_{\text {groundwater }}-\mathrm{V}_{\text {evaporation }} \\
\Delta \mathrm{S}=\mathrm{S}_{\text {runoff }}+\mathrm{S}_{\text {groundwater }}-\mathrm{S}_{\text {saltdust }}
\end{gathered}
$$

In Equation (1), $\Delta \mathrm{V}$ represents the annual variations in the lake volume; $\mathrm{V}_{\text {rainfall }}$ is the annual rainfall in the lake area; $V_{\text {runoff }}$ denotes the annual runoff of the inflowing river; $\mathrm{V}_{\text {groundwater }}$ is the groundwater discharge; and $\mathrm{V}_{\text {evaporation }}$ represents the annual evaporation of the lake area, and the units are all $\mathrm{m}^{3} / \mathrm{a}$. In Equation (2), $\Delta \mathrm{S}$ is the annual variation of the total salt content; $S_{\text {runoff }}$ is the annual inflow salt levels of the surface runoff; $S_{\text {groundwater }}$ is the inflow salt levels of the underground water; and $\mathrm{S}_{\text {saltdust }}$ denotes the salt dust losses in the lake area, and all of the units are t/a.

\section{$D$ mathematical model of the water quality}

Based on the analysis results of the water-salt balance in the lake, in order to accurately analyze and inverse the variations in the area and salinity of Ebinur Lake, as well as the effects of the water supplements, a 2D flow-pollutant mathematic model was used for the simulation and calculation processes in this study. The $2 \mathrm{D}$ water flow movement basic equations describing the wind-driven lake flow in Ebinur Lake were shown as follows (D.H.I, 2010):

$$
\begin{gathered}
\frac{\partial \varsigma}{\partial t}+\frac{\partial p}{\partial x}+\frac{\partial q}{\partial y}=\frac{\partial d}{\partial t} \\
\frac{\partial p}{\partial t}+\frac{\partial}{\partial x}\left(\frac{p^{2}}{h}\right)+\frac{\partial}{\partial y}\left(\frac{p q}{h}\right)+g h \frac{\partial \varsigma}{\partial x}+\frac{g p \sqrt{p^{2}+q^{2}}}{C^{2} \cdot h^{2}}-\Omega q-f V V_{x}+\frac{h}{\rho_{w}} \frac{\partial}{\partial x}\left(p_{\alpha}\right)-E\left[\frac{\partial^{2} q}{\partial x^{2}}+\frac{\partial^{2} q}{\partial y^{2}}\right]=0 \\
\frac{\partial q}{\partial t}+\frac{\partial}{\partial y}\left(\frac{q^{2}}{h}\right)+\frac{\partial}{\partial x}\left(\frac{p q}{h}\right)+g h \frac{\partial \varsigma}{\partial y}+\frac{g p \sqrt{p^{2}+q^{2}}}{C^{2} \cdot h^{2}}+\Omega p-f V V_{y}+\frac{h}{\rho_{w}} \frac{\partial}{\partial y}\left(p_{\alpha}\right)-E\left[\frac{\partial^{2} q}{\partial x^{2}}+\frac{\partial^{2} q}{\partial y^{2}}\right]=0
\end{gathered}
$$

In the equation, $h$ represents the water depth $(\mathrm{m})$; $\mathrm{d}$ is the time-varying depth $(\mathrm{m})$; $\mathrm{s}$ denotes the lake level $(\mathrm{m}) ; \mathrm{p}$ and $\mathrm{q}$ are the flux in the $\mathrm{x}$ and $\mathrm{y}$ directions, respectively $\left(\mathrm{m}^{3} / \mathrm{s} / \mathrm{m}\right)$, and $p=h u, q=h v ; u$ and $v$ are the average flow rate in the $\mathrm{x}$ and $\mathrm{y}$ 
directions, respectively; $\mathrm{C}$ represents the Chezy coefficient $\left(\mathrm{m}^{1 / 2} / \mathrm{s}\right) ; g$ is the gravitational acceleration $\left(\mathrm{m} / \mathrm{s}^{2}\right) ; f(V)$ denotes the wind resistance term; $\mathrm{V}, \mathrm{V}_{\mathrm{x}}$, and $\mathrm{V}_{\mathrm{y}}$ are the wind speed, $\mathrm{x}$-direction wind speed component, and $\mathrm{y}$-direction wind speed component $(\mathrm{m} / \mathrm{s})$, respectively; $\Omega$ is the Earth rotation Coriolis force coefficient, which is related to the latitude $\left(\mathrm{s}^{-1}\right) ; \mathrm{P}_{\mathrm{a}}$ is the atmospheric pressure $\left(\mathrm{kg} / \mathrm{m} / \mathrm{s}^{2}\right) ; \rho_{w}$ represents the density of the water $\left(\mathrm{kg} / \mathrm{m}^{3}\right) ; x, y$ is the spatial coordinate $(\mathrm{m}) ; t$ is the time coordinate (s); and E represents the eddy viscosity coefficient $\left(\mathrm{m}^{2} / \mathrm{s}\right)$.

In this research, the planar 2D mathematical equation of the salt movement could be described as follows:

$$
\frac{\partial}{\partial t}(h c)+\frac{\partial}{\partial x}(u h c)+\frac{\partial}{\partial y}(v h c)=\frac{\partial}{\partial x}\left[h D_{x} \frac{\partial c}{\partial x}\right]+\frac{\partial}{\partial y}\left[h D_{y} \frac{\partial c}{\partial y}\right]-\mathrm{k} h c+S
$$

Where $c$ is the transport salinity $(\mathrm{mg} / \mathrm{L}) ; u$ and $v$ are the horizontal components of the flow velocity in the $\mathrm{x}$ and $\mathrm{y}$ directions $(\mathrm{m} / \mathrm{s})$, respectively; h denotes the water depth (m); $D_{x}$ and $D_{y}$ are the diffusion coefficients in the $\mathrm{x}$ and $\mathrm{y}$ directions $\left(\mathrm{m}^{2} / \mathrm{s}\right)$, respectively; $\mathrm{k}$ is the attenuation coefficient $\left(\mathrm{s}^{-1}\right)$, in which the salt is an inert substance without decaying nor increasing, and only showing migration and diffusion movements with the water flow, k $=0 ; S$ represents the source-sink term, $S=Q_{s}\left(c_{s}-c\right) ; Q_{s}$ is the source or sink flow rate $\left(\mathrm{m}^{3} / \mathrm{s} / \mathrm{m}^{2}\right)$; and $c_{s}$ denotes the material concentration of the transport in the source or sink terms.

For the water quality mathematical model in this study, the measured area and salinity data of Ebinur Lake from 2005 to 2007 were used for the parameter calibration. Meanwhile, the measured data from 1956 to 2011 were adopted in order to validate the parameters (Fig. 3), which enabled the model to achieve better simulation effects.
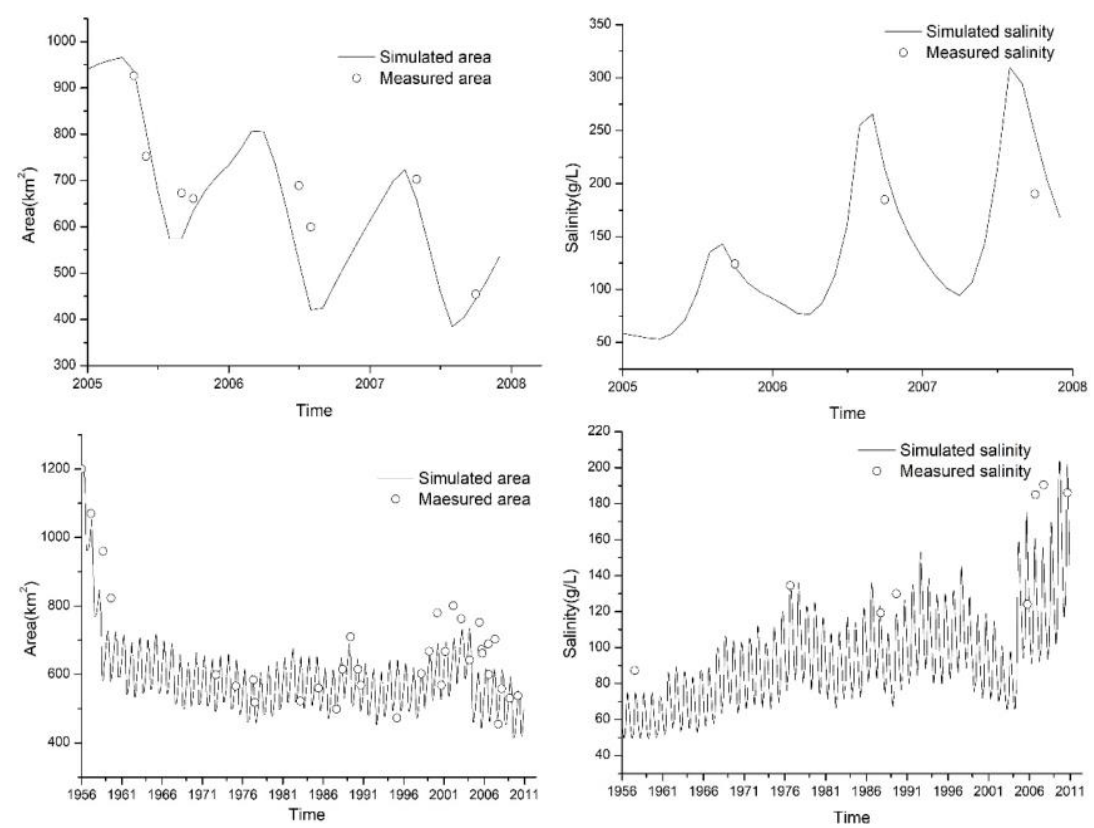

Figure 3. Results of the area calibration and validation for Ebinur Lake 


\section{Results and discussion}

\section{Analysis of the ecological effects of the water supplementation and water supplement processes of Ebinur Lake}

In this study, water balance analysis was conducted on the basis of the current water resource conditions (hereinafter referred to as "the current conditions") in the Ebinur Lake area. The volume of the lake was 468 million $\mathrm{m}^{3}$, which was the average inflow runoff from 2007 to 2010. In accordance with the related geological survey results of the groundwater recharge, the multi-year average phreatic water supply was 20 million $\mathrm{m}^{3}$, and the infiltration supply of confined water was 77 million $\mathrm{m}^{3}$. Combined with the current evaporation and rainfall monitoring results, it was determined that the lake area could be stably maintained under the current conditions of approximately $470 \mathrm{~km}^{2}$. In addition, during this investion, the analysis of the Ebinur Lake terrain revealed that when the water depth was less than $2.54 \mathrm{~m}$, the lake water level fell below the elevation of the transverse sand ridge on the lake-bed, and Ebinur Lake was effectively divided into two lakes: a small lake and a big lake. The small lake had no surface water supply, and quickly receded under the effects of the high winds in the Alataw Pass. When the water depth was higher than $2.54 \mathrm{~m}$, the big lake and small lake sections of Ebinur Lake were connected, and the small lake became stabilized, able to maintain a larger lake surface (Fig. 4). Under the current conditions, the water depth of the lake is less than $2.54 \mathrm{~m}$, and the corresponding lake area is $470 \mathrm{~km}^{2}$. Besides, the small lake is separated from the big lake, and has effectively receded. These results were found to be accordant with the results of the current lake area obtained by remote sensing monitoring.



Figure 4. Area-water depth curve and restoration target of Ebinur Lake

In the current study, under the restrictions of additional amounts of water, in order to achieve the maximum ecological benefits, the "lake area-water depth curve" were combined for analysis purposes, as shown in Fig. 4. Additionally, under the condition of the water depth being greater than $2.54 \mathrm{~m}$, the maximum efficiency of the water supplement was reached in the water depth interval corresponding to maximum variation rate of the lake area. Accordingly, the water depth restoration target was determined to be $2.71 \mathrm{~m}$ under the water supplement conditions of Ebinur Lake, and the 
corresponding lake area was $755 \mathrm{~km}^{2}$. Furthermore, based on this study's water balance analysis, the additional water required for such restoration target was determined to be approximately 366 million $\mathrm{m}^{3}$. Considering that the spring high winds from March to May mainly induce sandstorm disasters, the water supplement process was determined to involve uniform water supplements from the Jing River (without a drying up process occurring annually) during October - next March, and the water supplement flow should be approximately $23.3 \mathrm{~m}^{3} / \mathrm{s}$. This effective water supplementation would lead to a maximum lake area ocurring in the spring months.

In this study, the salt balance of Ebinur Lake was analyzed under both the current conditions and the water supplement conditions. It was found that under the current conditions, according to the actual measurement data of the current salinity in the lake area, the salinity in 2011 was between 166.0 and $207.0 \mathrm{~g} / \mathrm{L}$, with an average of $190 \mathrm{~g} / \mathrm{L}$. Besides, the salt content of Ebinur Lake was 79 million t. The measured multi-year average salinity levels of the Jing and Bortala Rivers were $240 \mathrm{mg} / \mathrm{L}$ and $700 \mathrm{mg} / \mathrm{L}$, respectively. Accordingly, the annual inflow salt levels of the surface runoff was $282,000 \mathrm{t}$. The actually measured salinity of the phreatic water was $2 \mathrm{~g} / \mathrm{L}$, resulting in the calculated lake inflow salt level of the groundwater reaching 40,000 t. Under the water supplement conditions, the newly-added salt levels following the increases in the lake's area were calculated according to the sampling analysis of the drying lakebed compositions. The lake was determined to be mainly composed of three soluble salts: crystal salt crust, salt-mud-clay crust, and wind erosion-accumulation crust. Due to the limited data, a one-third generalized computation was conducted for each of the three compositions. It was determined that the saline soil density was $2.8 \times 10^{3} \mathrm{~kg} / \mathrm{m}^{3}$. Accordingly, the lake's area following the water supplements was estimated to have increased by $285 \mathrm{~km}^{2}$, and approximately 10.99 million t of salt was estimated to be in the lake (Abuduwaili, 2012; Jin, 1995; Liu et al., 2009). Therefore, the total salt content level after the area size change of the lake was the sum of the above components (89.9 million $\mathrm{t}$ ), and the corresponding average lake salinity was determined to be $112 \mathrm{~g} / \mathrm{L}$.

\section{Ecological benefits of the water supplements in Ebinur Lake}

Due to the lack of long-term monitoring data under the present situation of the lake, the above water quality mathematical model was used to inverse the area size variations and salinity levels of Ebinur Lake in this study. The model was based on the measured river inflow data from 1956 to 2011 to measure the actual river inflow conditions. Meanwhile, the river flow was increased under the water supplement conditions for simulation purposes, in order to compare and analyze the impacts of the water supplements on area size and water salinity levels of the lake.

\section{Analysis of the changes in the lake's flow field}

According to the results of the simulation analysis, the wind speeds over Ebinur Lake were high, and the wind force was the main source power source of the lake's water movements. These wind-driven flow motions were determined to be the main lake flow circulation characteristic of Ebinur Lake (Fig. 5). The lake was dominated by northwest winds from the Alataw Pass all year round, with continuous surface water upwelling under the load of the strong winds. These conditions led to an accumulation of lake water and the higher water levels in the south-eastern end of the lake. Meanwhile, the water levels were observed to have fallen in the north-western end of the lake, with evident lake surface tilting. Under the combined effects from the pressure gradient force 
and the lakebed friction resistance generated by the wind shear stress and water-head pressure, it was found that two circulations with opposite flow directions were formed parallel to the wind direction along the "WN-ES" axis of the lake. In other words, a clockwise circulation existed in the northeastern side of the axis, and a counterclockwise circulation existed in the southwestern side of the axis. Under the water supplement conditions, the supplemented water amount was less than the water storage capacity of the lake. The driving effects which were generated by the inflow water and lake water exchange were found to be minimal, and the resulting influences were basically covered by the wind-driven flow without changing the distribution form of the entire flow field. Therefore, only minimal differences in the lake flow field distribution were observed when comparing the conditions before and after the water supplements.

(1) March under the actual river inflow conditions

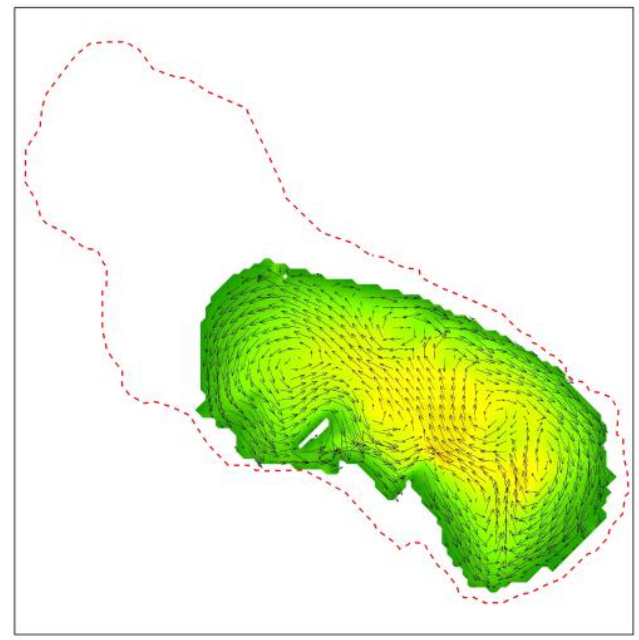

(3) March under the water supplement conditions

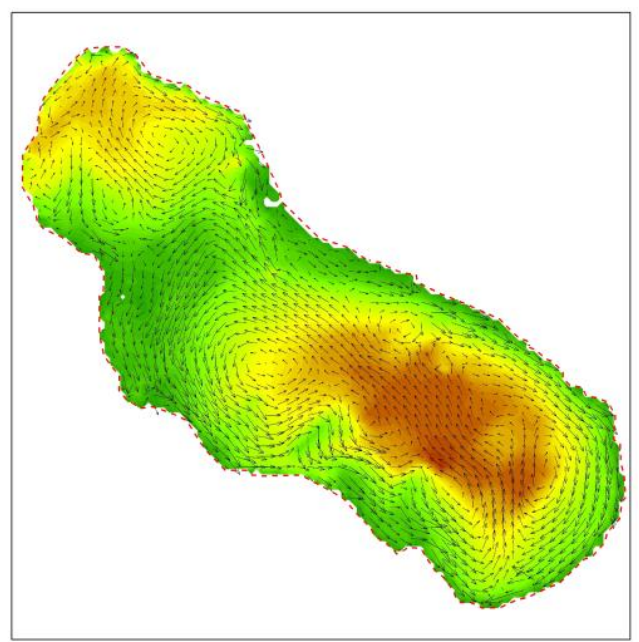

(2) September under the actual river inflow conditions



Flow rate



Water depth $(\mathrm{m})$

(4) September under the water supplement conditions

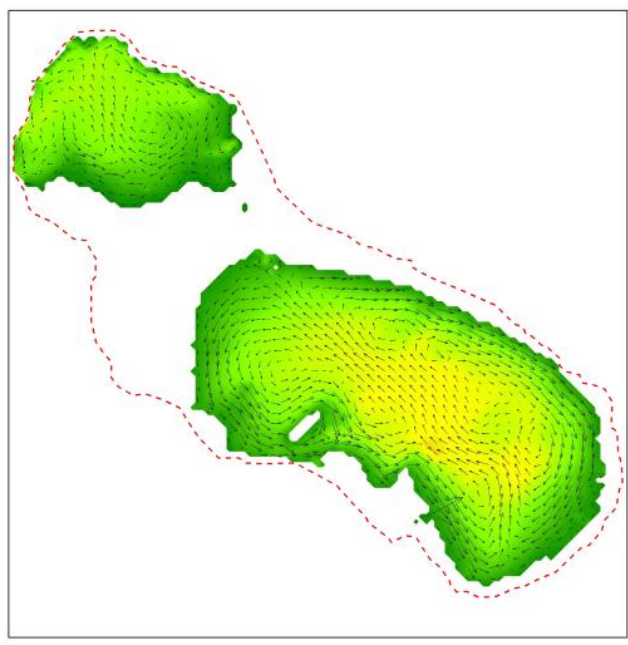

Figure 5. Distribution diagram of the typical flow fields of Ebinur Lake under the two conditions examined in this study 


\section{Analysis of the ecological effects}

\section{(1) Variations in the size of the lake's water area}

It was found that through analyzing the simulated lake area variations under the two types of conditions (Figs. 6 and 7), the lake area under the actual river inflow conditions was reduced, and the multi-year average lake area was $387 \mathrm{~km}^{2}$. The small lake had totally receded during the entire year, while only the big lake displayed flowing water conditions. The area was found to change regularly with the hydrological cycle. For example, from April to September, the lake area reduced, with an average area of 366 $\mathrm{km}^{2}$. Later, from October to March of the following year, the area of the lake gradually increased, with an average area of $407 \mathrm{~km}^{2}$. The maximum area size of $468 \mathrm{~km}^{2}$ was shown in March, and the minimum area size of $315 \mathrm{~km}^{2}$ was shown in August. Under the water supplement conditions, it was observed that the lake area significantly increased during the early period of the water supplements, and a relative balance was achieved between the inflow and evaporation. The lake area was found to be in a relatively stable state. The multi-year average lake area had reached $661 \mathrm{~km}^{2}$, which was an increase of $274 \mathrm{~km}^{2}$ over the actual river inflow conditions. The change trends of each month were determined to be basically consistent with the actual river inflow situation. The average area size of the lake from April to September was $605 \mathrm{~km}^{2}$, and that from October to the following March was $719 \mathrm{~km}^{2}$, with a maximum area size of $834 \mathrm{~km}^{2}$ occurring in March, and a minimum area size of $508 \mathrm{~km}^{2}$ observed in September.

According to the above analysis, the area of Ebinur Lake will continue to shrink under the actual river inflow conditions. However, a water supplement program would effectively restore the area size of Ebinur Lake, particularly the small lake surface near the Alataw Pass. Under the spring high-wind conditions, the multi-year average lake area was found to reach a maximum level in a year. In addition, the water supplements were determined to effectively mitigate the effects of the regional salt dust during the spring seasons.

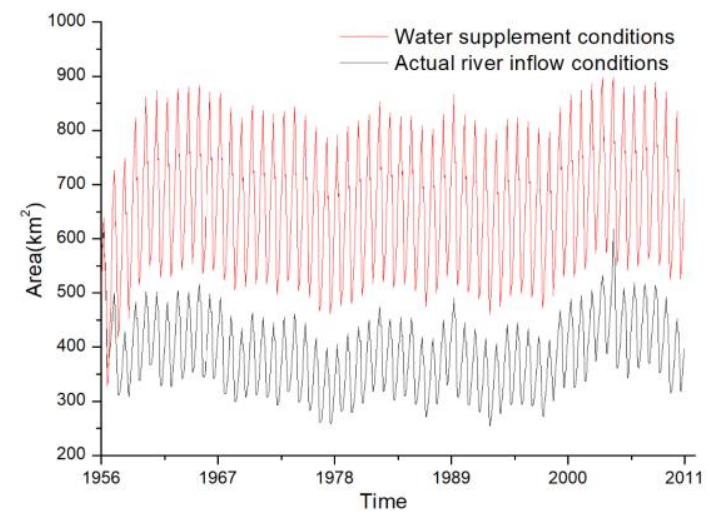

Figure 6. Area changes of Ebinur Lake

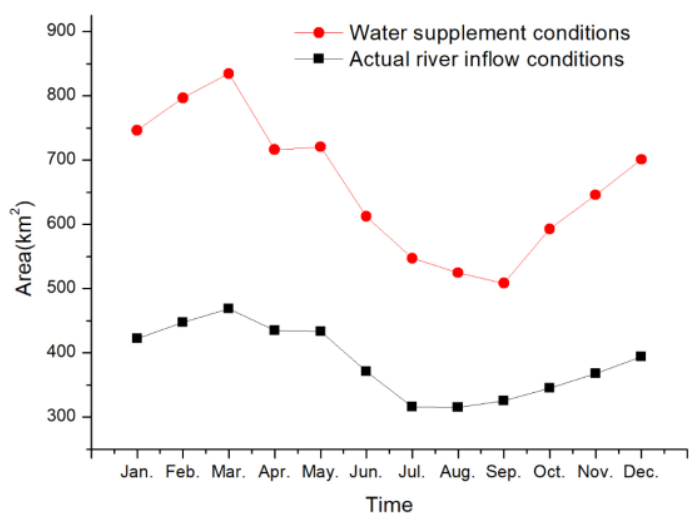

Figure 7. Contrasts of the multi-year monthly average area size of Ebinur Lake

\section{(2) Variations in the salinity levels of the lake}

In this research, it was determined from the results of the simulation analysis on the long-term lake salinity levels that the increased lake area had effectively dissolved the 
original dry lakebed under the water supplement conditions, including the increment of lake inflow in addition to the freshwater dilution and evaporative concentration effects of lake area. This in turn led to greater amounts of salt entering into the lake as the lake's salinity distribution changed with the water circulation movements. Due to the dilution effects from the wind-driven flow superposition on the southwestern side of the lake, the salinity levels were found to have significantly changed. It was observed that the changes of the northeastern side were less than those on the southwestern side, and water supplements had mainly impacted the southwestern lake area (Fig. 8).

(1) March under the actual river inflow conditions

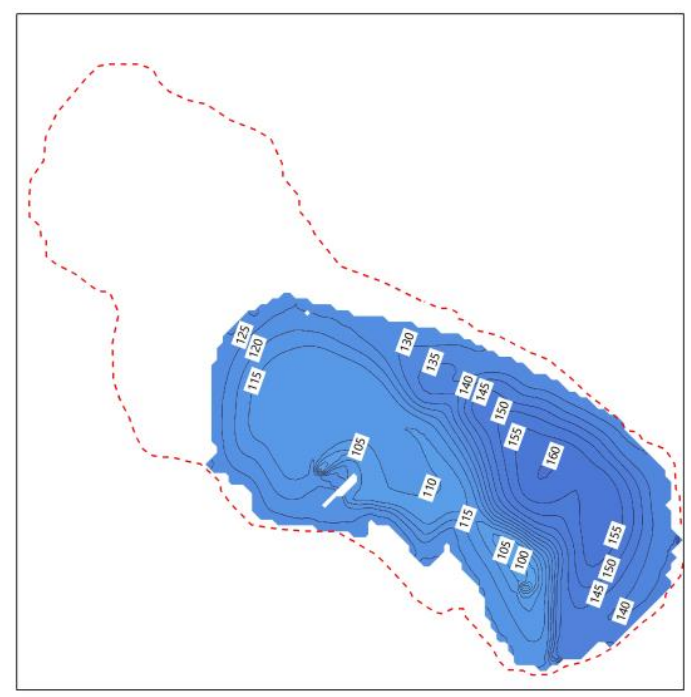

(3) March under the water supplement conditions



(2) September under the actual river inflow conditions

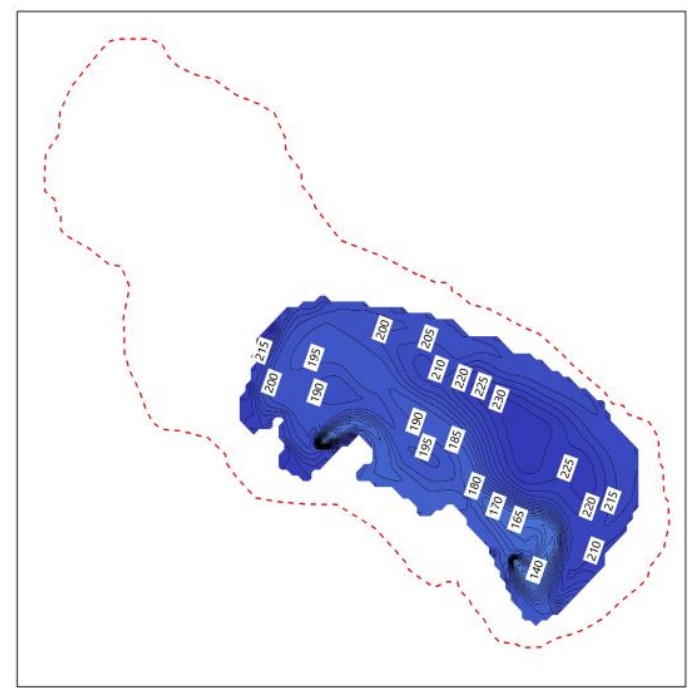

(4) September under the water supplement conditions

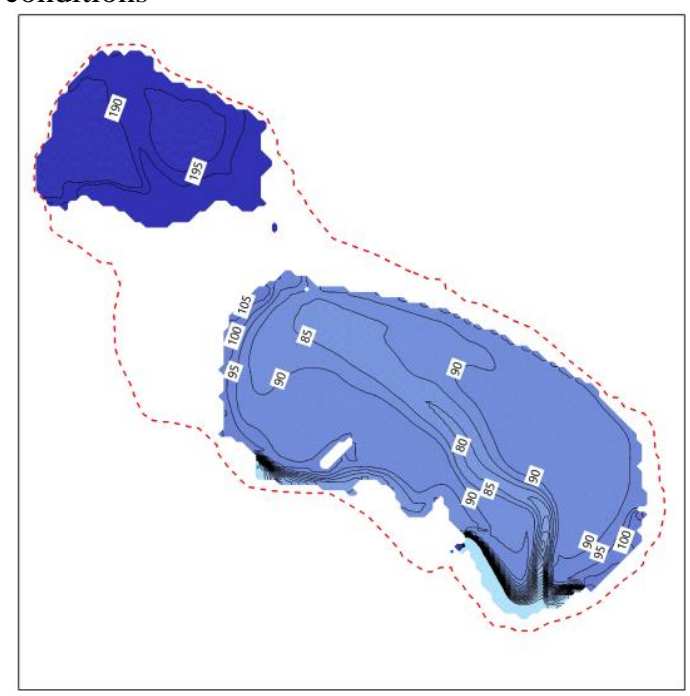

Figure 8. Salinity distribution in Ebinur Lake during the months of March and September

According to the comparison of the average salinity changes for the entire lake under the two examined conditions (Figs. 9 and 10), it was observed that during the first two or three years under the actual river inflow conditions, due to the decreases in the area size of the lake, the salinity levels continued to rise. Subsequently, with the stabilization 
of the lake area, the salinity maintained at a relatively stable level. The whole-lake multi-year average salinity had increased to $173 \mathrm{~g} / \mathrm{L}$, and the minimum monthly average salinity level appeared in March (120 g/L). From July to September, the monthly average salinity was determined to exceed $200 \mathrm{~g} / \mathrm{L}$, with the maximum $(248 \mathrm{~g} / \mathrm{L})$ shown in September. Under the water supplement conditions, it was observed that during the early period, due to the increases in the area of Ebinur Lake, the salinity level was declining, which was followed by a relatively stable state. The multi-year average salinity was determined to be $102 \mathrm{~g} / \mathrm{L}$ approximately, with the minimum of monthly average salinity level appearing in March $(66.92 \mathrm{~g} / \mathrm{L})$, and the maximum shown in August (149.31 g/L).

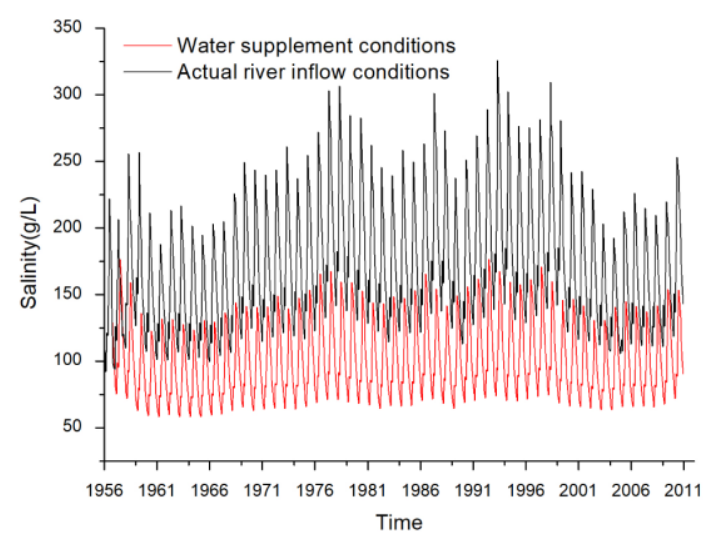

Figure 9. Interannual variations in the whole-lake average salinity levels



Figure 10. Distributions of the monthly whole-lake average salinity

Through further analyzing of the salinity changes under the two examined conditions, the salinity was divided into five grades in accordance with the concentrations as follows: $<50 \mathrm{~g} / \mathrm{L} ; 50$ to $100 \mathrm{~g} / \mathrm{L} ; 100$ to $150 \mathrm{~g} / \mathrm{L} ; 150$ to $200 \mathrm{~g} / \mathrm{L}$; and $>200 \mathrm{~g} / \mathrm{L}$, in order to analyze the monthly changes in area of each grade (Fig. 11).

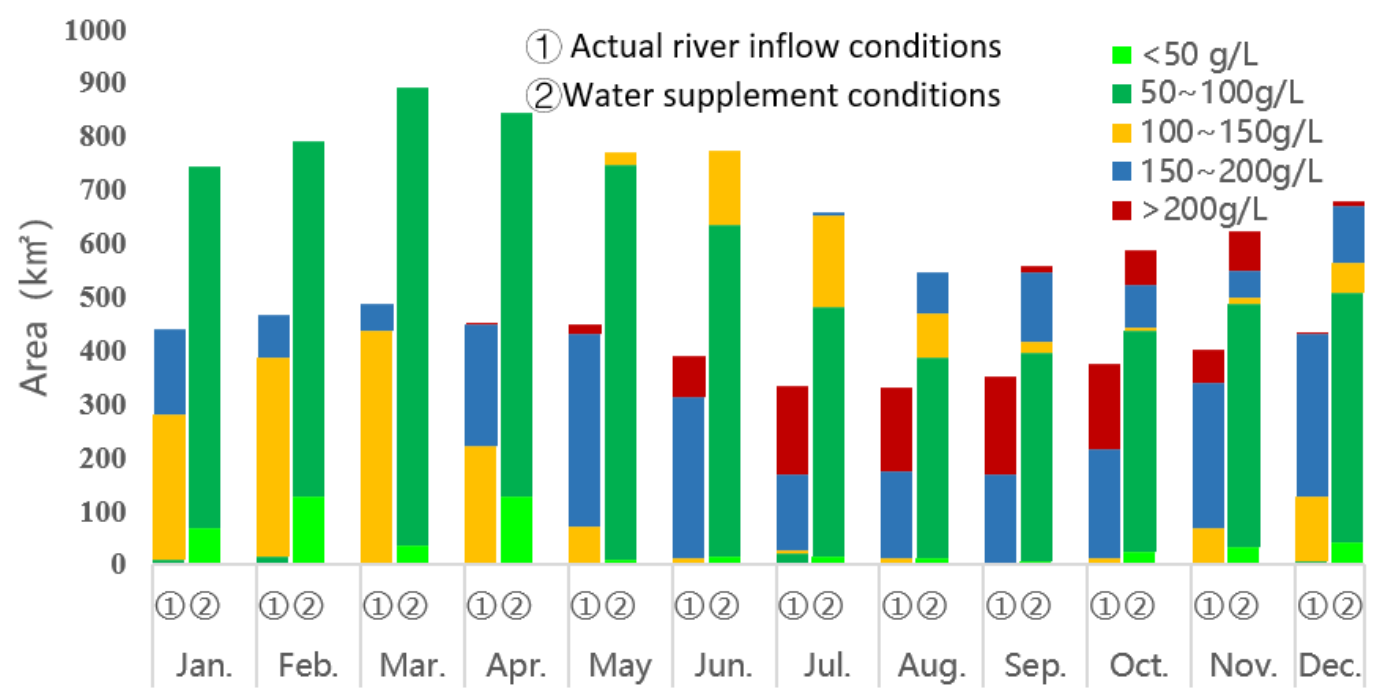

Figure 11. Monthly lake area distributions during every salinity period 
Under the actual river inflow conditions, the areas of Ebinur Lake with whole-year annual average salinity concentrations above $150 \mathrm{~g} / \mathrm{L}$ were the maximum, and accounted for $66 \%$ of the total area. There were no areas observed with salinity levels less than $50 \mathrm{~g} / \mathrm{L}$, and the areas with salinity levels between $50 \mathrm{~g} / \mathrm{L}$ and $150 \mathrm{~g} / \mathrm{L}$ accounted for $34 \%$ of the total lake area. It was found that from June to October, the areas with salinity levels between 50 and $150 \mathrm{~g} / \mathrm{L}$ were minimum, and accounted for less than $10 \%$. Under the water supplement conditions, the whole-lake salinity level had decreased; the whole-year salinity level was mainly concentrated in the range of 50 to $150 \mathrm{~g} / \mathrm{L}$, and the areas with such a salinity range accounted for $87 \%$ of the total lake area. The areas of the lake with the salinity levels above $150 \mathrm{~g} / \mathrm{L}$ only accounted for $7 \%$ of the entire lake area, and the areas with salinity levels above $150 \mathrm{~g} / \mathrm{L}$ from September to October accounted for the largest proportion, reaching approximately $25 \%$ of the total lake area.

In summary, the results of this study revealed that the salinity levels of the lake areas had significant negative correlations with the total lake area. Additionally, the salinity levels fluctuated periodically with the changes of the lake's area. Under the actual river inflow conditions, the salinity levels of Ebinur Lake continues to increase. For example, from July to September, the salinity in more than $90 \%$ of the area was greater than 150 $\mathrm{g} / \mathrm{L}$, which had serious impacts on the artemia growth in the lake. However, under the water supplement conditions, the salinity of the lake was significantly decreased. The areas with salinity levels greater than $150 \mathrm{~g} / \mathrm{L}$ had been greatly reduced, which was conducive to the growth of artemia in Ebinur Lake.

\section{Conclusions}

The following conclusions were drawn in this research study:

(1) The environmental water storage shortages in Ebinur Lake have caused a series of ecological environment problems. In this study, in accordance with the combined water-balance and terrain analysis, a restoration target for the ecological water supplements of Ebinur Lake was determined. It was estimated that when the water depth was increased to $2.71 \mathrm{~m}$, the corresponding lake area would be $755 \mathrm{~km}^{2}$. The water supplement amount required by such a target was determined to be 366 million $\mathrm{m}^{3}$. Besides, by considering the influences of the spring gale winds in the area, the water supplement process was defined as the uniform water supplement of the Jing River, with perennial water flowing from October to the next March. The water supplement flow would be $23.3 \mathrm{~m}^{3} / \mathrm{s}$, which in spring would lead to the maximum area of the lake.

(2) This study further analyzed the determined ecological water supplement restoration target and volume of Ebinur Lake. The inversion of the long-sequence river runoff during the period ranging from 1956 to 2011 was used to analyze the accessibility of the Ebinur Lake restoration target, as well to compare the differences in the area of the lake under both the actual river inflow and water supplement conditions. Under the actual river inflow conditions, the average multi-year lake area was $387 \mathrm{~km}^{2}$, and monthly area regularly changed with the hydrological cycle. During the spring gale season, the lake area was approximately $407 \mathrm{~km}^{2}$. Under the water supplement conditions, the average multi-year lake area was $661 \mathrm{~km}^{2}$, which was an increase of 274 $\mathrm{km}^{2}$ over the actual river inflow conditions. During the spring gale season, the lake area was approximately $834 \mathrm{~km}^{2}$. The small lake near the Alataw Pass was covered with water all year round with the water supplements, which effectively mitigated the 
influences of the regional salt dust. Therefore, the ecological water supplement amount which was determined in this study was confirmed to achieve the Ebinur Lake area restoration target.

(3) Through the simulated calculation of the long-sequence salinity under the two examined conditions, it was found that under the actual river inflow conditions, the average whole-lake multi-year salinity was $173 \mathrm{~g} / \mathrm{L}$. The lake areas which were suitable for artemia growth only accounted for $34 \%$ of the total lake area. The minimum salinity level of multi-year monthly average had reached $120 \mathrm{~g} / \mathrm{L}$ in March and the maximum was $248 \mathrm{~g} / \mathrm{L}$ shown in September. It was determined that the salinity levels in more than $90 \%$ of the lake areas were higher than $150 \mathrm{~g} / \mathrm{L}$. Under the water supplement conditions, the multi-year average salinity levels were approximately $102 \mathrm{~g} / \mathrm{L}$, and the areas with annual salinity concentrations ranging between $50 \mathrm{~g} / \mathrm{L}$ and $150 \mathrm{~g} / \mathrm{L}$ accounted for $87 \%$ of the total lake area. The minimum salinity level of monthly multiyear average had reached $66.92 \mathrm{~g} / \mathrm{L}$ in March, and the maximum was $149.31 \mathrm{~g} / \mathrm{L}$ shown in August. The areas with salinity levels higher than $150 \mathrm{~g} / \mathrm{L}$ in September and October accounted for $25 \%$ of the total lake area, and the maximum yearly salinity levels occurred at that time. The ecological water supplement amount determined in this study was found to effectively reduce the salinity of Ebinur Lake, which was conducive to the growth of artemia and improvements in the negative ecological situation of Ebinur Lake caused by limited water resources.

Lake ecological systems are complex processes which combine many factors, such as climate, hydrology and ecology. The restorations of lake ecosystems are known to be closely related to water supplement amounts, and are also correlated with the positions and processes of water supplementation. Therefore, the ecological issues of Ebinur Lake will require in-depth examinations in the future. Future studies performed on Ebinur Lake should be in a combination of the detailed lake area variations and the requirements of the lake's aquatic organisms, as well as other aspects, in order to determine the restoration and improvement targets for the ecological environment in Ebinur Lake.

Acknowledgements. This study was jointly funded by "IWHR Research\&Development Support Program (WE0145C162018). The authors would like to thank the staff for their involvement in this project.

\section{REFERENCES}

[1] Abuduwaili, J. (2012): Lakes of Arid Land and Salt-dust Storms. - China Environmental Science Press.

[2] Abuduwaili, J., Gabchenko, M. V., Junrong, X. (2008): Eolian Transport of Salts - A Case Study in the Area of Lake Ebinur (Xinjiang, Northwest China). - Journal of Arid Environments 72(10): 1843-1852.

[3] Bayahen, K. (2010): Seasonal Changes in the Number of Relict Gull (Larus relictus) at Ebinur Lake, Western China. - Journal of Arid Land 2(2): 151-155.

[4] Chen, Z. (2007): Study on the Causes and Impacts of Water-salt Change of Ebinur Lake. - Journal of Salt Lake Research 15(2): 1-5.

[5] D.H.I (Denmark). MIKE 21 \& MIKE 3 FLOW MODEL FM-Hydrodynamic and Transport Module Scientific Documentation 2011.

[6] Jin, X. (1995): Lakes in China. - Research of Their Environment. Beijing: China Ocean Press, 1995. 
[7] Liu, D., Abuduwaili, J., Mu, G., Xu, J. R. (2009): Chemical Components and Transport Mechanics of Wind-erodible Playa Sediments, Ebinur Lake, Xinjiang. - China Environmental Science 29(2): 157-162.

[8] Liu, D., Abuduwaili, J., Wang, L. (2014): Sediment Fluxes and Material Composition of the Salt Dust in Ebinur Lake Region, Xinjiang. - Journal of Glaciology and Geocryology 36(2): 352-359.

[9] Ma, M., Bayahen, K., Li, F., Hu, B., Wu, J., Douglas, M. (2010): List of Birds and Count of Autumn Migration in Ebinur Wetland Nature Reserve. - Sichuan Journal of Zoology 29(6): 912-918.

[10] Mulian, R., Wenrong, Y., Zuofa, J. et al. (1992): Artemia in Ebinur Lake, Xinjiang. Xinjiang: Xinjiang Science and Technology Press, 1992.

[11] Riveros-Iregui, D. A., Lenters, J. D., Peake, C. S. (2017): Evaporation from a shallow, saline lake in the Nebraska Sandhills: Energy balance drivers of seasonal and interannual variability. - Journal of Hydrology 553: 172-187.

[12] Sheng, D., Li, J., Sun, F., He, X., Yang, G. (2010): Study on Water Salt Change of Some in Land Lakes in Arid Areas and the Control Mechanism. - Arid Zone Research 27(4): 529-535.

[13] Su Qin (2015): Study on Spatial and Temporal Changes of Water Quality and Its Managerial Strategies in Ebinur Lake. Xinjiang Agriculture University, 2015.

[14] Sumin, W., Hongshen, D. (1998): Chinese Lake Chronicles. Beijing: Science and Technology Press, 1998.

[15] Wang, X., Zhang, F., Kung, H. T., Ghulam, A., Trumbo, A. L., Yang, J., Ren, Y., Jing, Y. (2017): Evaluation and Estimation of Surface Water Quality in an Arid Region Based on EEM-PARAFAC and 3D Fluorescence Spectral Index: A Case Study of the Ebinur Lake Watershed, China. Catena, 2017.

[16] Yan, L., Sun, M., Yao, X. et al. (2018): Lake Water in the Tibet Plateau: Quality Change and Current Status Evaluation. - Acta Scientiae Circumstantiae 38(3): 899-910.

[17] Zhang, F., Wang, J., Tashpolat, T., Zhou, M. (2015): The spatial and temporal dynamic changes and driving forces in the surface area of ebinur lake from 1998-2013. - Acta Ecologica Sinica 35(9): 2848-2859.

[18] Zhu, S., Zhang, F., Zhang, H. (2018): The Seasonal and Spatial Variations of Water Chemistry of River in Ebinur Lake Basin. - Acta Scientiae Circumstantiae 38(3): 892899. 